DAVID ROBIE is director of the Pacific Media Centre.

\section{The paradox of two countries called Fiji}

Stopover, by Bruce Connew. Wellington: Victoria University Press, 2007. 188 pp. ISBN 978084735577.

CEVEN years ago, photojournalNist Bruce Connew travelled to Fiji as an eyewitness to the suffering experienced by poor cane cutters in the wake of George Speight's putsch. Speight and his co-conspirators had seized Parliament and held Labour Prime Minister Mahendra Chaudhry and his government at gunpoint for 56 days.

At the time, Connew's two elder daughters in New Zealand both had Fiji partners - one an indigenous Fijian on a university studies scholarship, and the other an Indo-Fijian whose family had emigrated from Fiji after Sitiveni Rabuka's 1987 coups. Connew recalls:

They are almost as dear to me as my daughters. They get on well, and

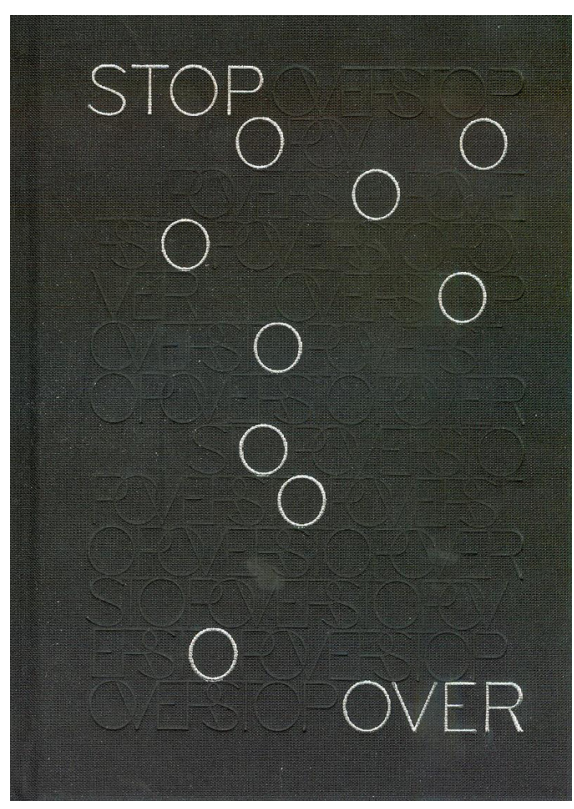

in fact once lived not far from each other in a middle-class suburb of Suva. But when we sat around the table talking after George Speight had stormed Parliament, it brought to mind other conversations we'd had. I can remember thinking during some of these conversations that each of them was describing a different Fiji, a different country almost.

Connew profiled the paradox of 'two countries called Fiji' in the Listener (2000). Between thatyearand November 2003 he has returned six times to Fiji, visiting sugar cane cutting gang \#18 members and their families on leased 20ha plots in Vatiyaka, a valley in western Viti Levu. 


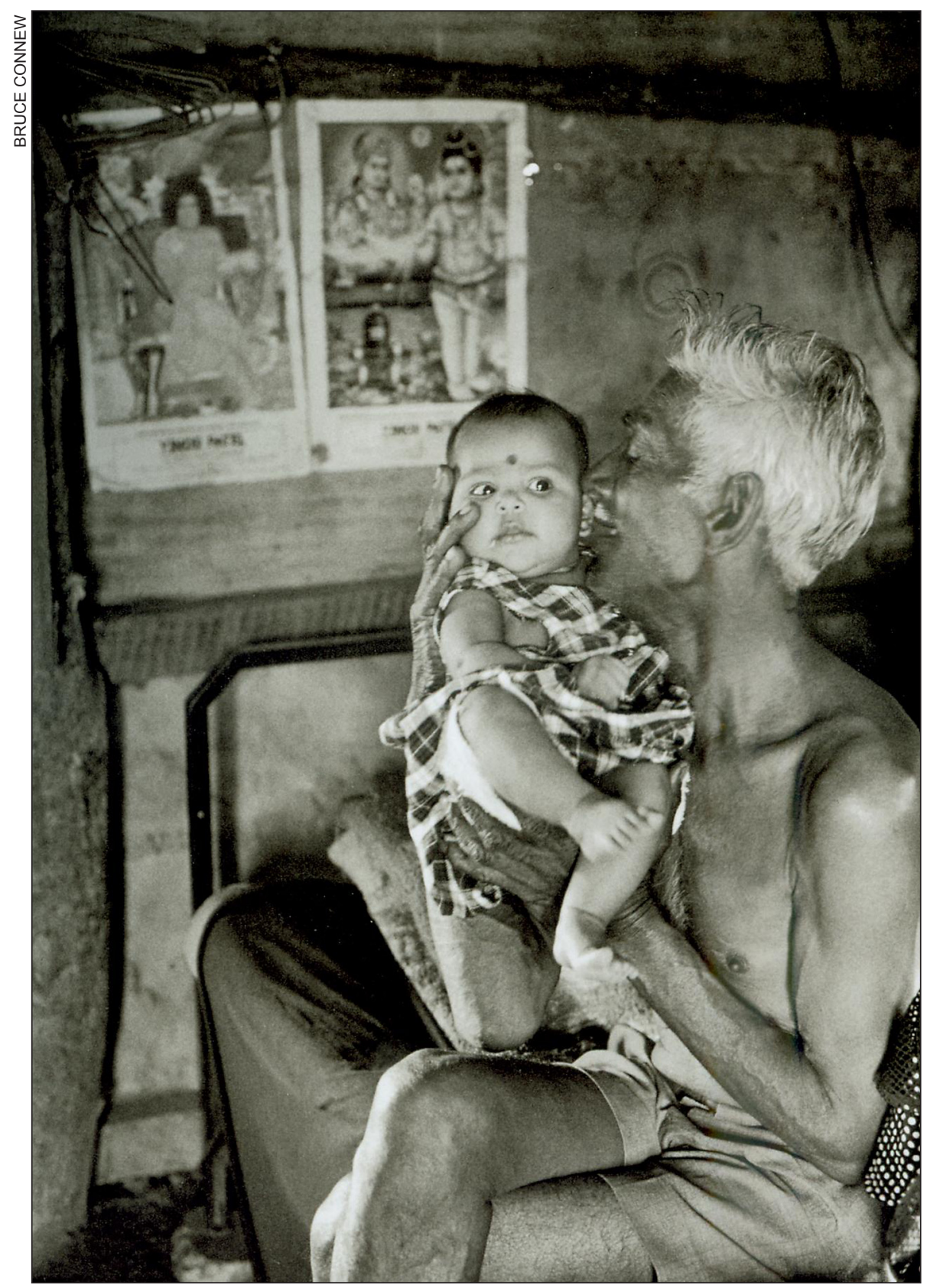

208 PACIFIC JOURNALISM REVIEW 13 (2) 2007 
This book, Stopover, is a poignant documentary of the lives of the cane families and a story of migration. It is illustrated with some 59 sepiatoned Connew portraits and other studies, seven diaspora snapshots, two grainy Speight television images and a faded image of two unknown men, earlier descendants (c. 1940s) of the girmitiya, $19^{\text {th }}$ century indentured labourers brought to Fiji by the British colonialists to establish the sugar plantations.

The book is also graced with the evocative story 'Mr Arjun' by Brij Lal, professor of Pacific and Asian history at the Australian National University, about an illiterate Indo-Fijian villager from Tabia near Labasa, on the island of Vanua Levu.

Some of Connew's photos feature the cane families and their homelife, cooking on open fires and kerosene burners, planting, working the cane, burning off, harvesting, loading up the trucks, births, birthdays, weddings and Ram Naumi, the eight-night Hindu festival leading to the day of Lord Rama's birth.

Since being photographed by Connew, some of the gang \#18 cutters and their families have emigrated to Australia, New Zealand, California

\section{Opposite: Vatiyaka cane farmer Ram Khelwan hugs his granddaughter Sarina.}

and Hawai' $i$ - and, of course, there have been births and deaths. Connew and Lal launched Stopover on location at Vatiyaka in August, sharing with the families still there .

Connew has forged an impressive reputation as a social and political photographer who 'has always been a celebrant of human resistance in tight places', as expressed by Justin Paton in Landfall. In 1981, while a contract photographer for the Listener, he was among a group of photographers who chronicled 'New Zealand's shame' during the repression aimed at anti-apartheid protesters during the Springbok rugby union tour that year.

Four years later, he visited South Africa on the eve of a planned and controversial rugby tour expressly to 'look on the other side of the fence' about apartheid. The tour was cancelled after a NZ court ruled the tour would bring the game of rugby into disrepute.

Photographs from Connew's tour became a book, South Africa (1987). In 1984, he pictured Kanak independence leader Eloi Machoro's rebel encampment near Thio, New Caledonia, just two weeks before French forces shot dead the schoolteacher regarded by some as the Pacific's Che Guevara.

In 1989, Connew journeyed to 
the Burmese jungle to report on the struggle by the Karen ethnic minority against the military. His pictures led to another book, On the Way to an Ambush (1999).

Like Ambush, Catherine Griffiths has superbly designed Stopover, including the use of textured paper.

In Stopover, Connew explains with empathy why third, fourth and fifth generation Indo-Fijians, forbidden to own land in Fiji, 'suppose their future lies beyond the country of their birth'. After four coups, the migration flow to First World countries continues unabated. As the author observes:

A coup is a blunt instrument, even when bringing down an elected government deserving of not much compassion. It is unfortunate that Pacific leaders New Zealand and Australia, during the years since the Speight coup, failed to sufficiently encourage fitting governance out of Fiji's elected administration.

\section{References}

Connew, B. (2000, September 9). Two countries called Fiji. NZ Listener, pp. 32-35. 58-59.

Connew, B. (1999). On the way to an ambush. Wellington: Victoria University Press.

Connew, B. and Wright, V. (1987). South Africa. Auckland: Hodder and Stoughton

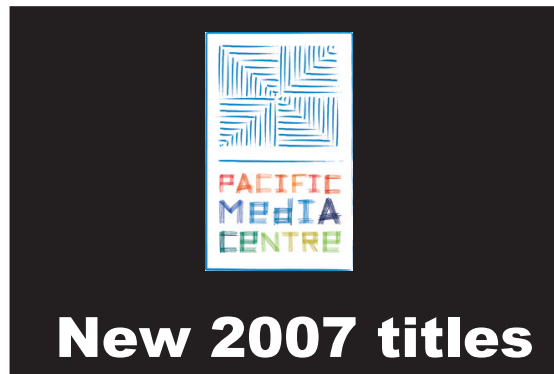

Development and the Media in the Pacific Biman Prasad and Shailendra Singh (Eds.)

- Development journalism

- Reporting the economy

- Freedom of information

- Sustainable development

- Environment

South Pacific Islands Communication: Local initiatives, regional perspectives Evangelia Papoutsaki and Usha Harris (Eds.)

A collection of Pacific research papers from the 2005, 2006 and 2007 AMIC conferences

Order now: Pacific Media Centre AUT University Private Bag 92006 Auckland 1142 Aotearoa/New Zealand pmc@aut.ac.nz www.pmc.aut.ac 